\title{
Staple food choices in Samoa: Do changing dietary trends reflect local food preferences?
}

\author{
A. Maxwell. P. Jones, Hannes Dempewolf, Rebecca Armstrong, \\ Kathy Gallucci, and Namulau`ulu Gaugau Tavana
}

\section{Research}

\begin{abstract}
The prevalence of non-communicable diseases such as diabetes, obesity and cardiovascular disease has become a considerable health problem throughout the South $\mathrm{Pa}$ cific, including Samoa. The increase in these diseases is most often associated with changes in dietary intake; including increased consumption of fats and sugars concurrent with reduced consumption of fibre and complex carbohydrates. We conducted this study in order to better understand food preferences in the Samoan population. The study focuses on the following common staple foods available in Samoa: taro, banana, elephant ear, yam, breadfruit, tapioca, rice, bread, noodles and potatoes. Interviews were conducted with 51 volunteers to better understand what foods they prefer to eat, which items they viewed as healthy choices, and how they categorize and view these foods. Over all, the participants preferred the traditional foods over imported staples. The local foods were preferred because they are considered to be healthier choices and provide a longer lasting source of energy. The preference ranking assigned to the food items correlated with their documented glycemic indexes (GI). Although it appears that Samoans prefer low GI, fiber-rich staple foods, imported refined cereal products provide more calories for the same price which makes them more economical. We recommend that future public health policy in Samoa should focus on the preference for healthier, more sustainable local foods, and aim at making these foods more economically competitive.
\end{abstract}

\section{Abstract (Samoan)}

O le mata utia o fa`ama i lē pipisi e pei o le suka, puta, ma gasegase o le fatu ua avea ma fa afitauli matuiā o le soifua maloloina i le Pasefika i Saute, e aofia ai ma Samoa. O le fa`atupula ia o nei fa`ama`i ua feso ota`i vavalalata ma le suiga i mea`ai e aofia ai le fa`ateleina o le taumafaina o mea`ai ga`o ma suka ae ua fa`aitiitia le taumafaina o me`ai e maua ai vaitamini ma le masoā. Sa matou faia lenei su’esu'ega ina ia malamalama lelei ai i ituaiga o mea ai e fiafia iai tagata Samoa. Sa fa`apitoa le su`esu`ega i mea`ai e masani ona maua i Samoa; talo, fa i, ta`amū, manioka, alaisa, falaoa, saimini, ma pateta. Sa fa`atalanoaina tagata e 51 ina ia malamalama lelei ai ituaiga mea`ai latou e fiafia iai, o mea ai ua latou manatu e aogā mo le soifua maloloina, fa`atasi ai ma le fa`avasegaina ma le malamalama i nei mea`ai. I le aotelega, na sili atu le fiafia o i latou na auai i le su`esu`ega i mea`ai masani o lo`o maua i Samoa nai lo mea`ai masani o lo`o fa`atau mai fafo. O lenei fa ai uga e tutusa lelei i tamaiti ma tagata matutua, ma tamaloloa ma fafine. E sili atu le fiafia o Samoa i nei mea ai ona ua manatu e aoga mo le soifua maloloina, ma e umi o maua ai le malosi. 0

\section{Correspondence}

A. Maxwell. P. Jones, Department of Biology, University of British Columbia Okanagan, 3333 University Way, Kelowna, BC, V1V 1V7, CANADA. Max.Jones@ubc.ca

Hannes Dempewolf, Biodiversity Research Centre \& Department of Botany, University of British Columbia,3529-6270 University Blvd, Vancouver, BC, V6T 1Z4, CANADA. handem@interchange.ubc.ca

Rebecca Armstrong, College of Biological Sciences, University of Minnesota, 123 Snyder Hall, 1475 Gortner Ave., St. Paul, MN 55108, U.S.A. armst192@umn.edu

Kathy Gallucci, Biology Department, 2625 Campus Box, Elon University, Elon, NC 27244, U.S.A. gallucci@elon.edu Namulau'ulu Gaugau Tavana, 795 N 2770 W, Provo, UT 84601, U.S.A.ngtavana@gmail.com

Ethnobotany Research \& Applications 9:455-462 (2011)

Published: December 23, 2011 
le fa`atulagaina o mea`ai e tusa ai ma lona mana`omia ua talafeagai lelei ma lo latou fa`atulagaga i le GI (o le fua o le àafiaga o mea`ai i le maualuga o le suka). E ui ina foliga mai e fiafia Samoa i mea ai e maulalo le GI, o mea ai e tele ai le fiber, o mea`ai masoa e gaosi ma fa'atau mai fafo e sili atu le malosi e maua mai ai ma e tutusa le tau ma avea ma mea ua faigofie ai ona fa atauina. $O$ aiaiga o le lumana i o le soifua maloloina o tagata o Samoa e ao ona fa`aaoga lenei fa`ai uga mo mea ai e fiafia iai mo le soifua maloloina lelei, ia maua pea lave pea nei mea'ai e masani ai, ma fuafua ina ia gafatia le tau.

\section{Introduction}

Throughout much of the Pacific, indigenous people's dietary consumption has undergone profound transformations in recent decades due to increased trade and rapid economic modernization (Coyne 2000). Though the shift from traditional diets to modern foods has been most profound in urban areas, rural areas are also being increasingly affected. Present-day diets of many people in $\mathrm{Pa}$ cific communities are typically higher in fat and protein but lower in complex carbohydrates and fiber than traditional diets - a trend some theorize has led to higher incidences of non-communicable diseases such as obesity, cardiovascular disease, diabetes mellitus as well as several types of cancer (Coyne 2000, WHO 1990). This pattern holds true for the Polynesian island nation of Samoa (Collins et al. 1994, Galanis et al. 1995, Galanis et al. 1999, Hodge et al. 1994). A wide variety of staple foods from various parts of the world have become readily available in Samoa during the past decades, which have led to a profound change in the type and diversity of foods being consumed. A traditional Samoan meal is usually centered on a choice of starchy staples, accompanied by a 'protein, fat or sweet-flavoured relish,' often made with coconut cream and served with fish, chicken or pork at special occasions (Holmes 1958). In recent decades however, imported foodstuffs such as mutton flaps, turkey tails, white rice, flour and sugar are available at low cost and hence consumed at much higher proportions (Quested et al. 1992). Staple foods in traditional meals are mainly starchy bananas (fa'i; Musa acuminata x balbisiana Colla), breadfruit (ulu; Artocarpus altilis (Parkinson) Fosberg), elephant ear (ta`amū; Alocasia macrorrhizos (L.) G. Don), taro (talo; Colocasia esculenta (L.) Schott), tapioca made from manioc (manioka; Manihot esculenta Crantz) and yam (ufi; Dioscorea alata L.) (Holmes 1958, Watters 1958, Whistler 2000). Modern additions to the array of starchy foodstuffs include white rice (alaisa; Oryza sativa L.), wheat bread (falaoa; Triticum spp.), potatoes (pateta; Solanum tuberosum L.) and noodles (saimini) made from wheat or rice flour.

Although the proportion of imported starch staples in the diet of Samoans seems to be on the rise, it is unclear whether Samoans have a preference for non-traditional starchy staples or if it is a result of economics and/or convenience. Furthermore, one might expect younger Samoans to show a greater preference for non-traditional starchy foods due to an increased exposure to a modern diet at a young age, however so far this has not been investigated. In the present study, interviews were conducted in rural and urban areas with Samoans of different age groups to better understand what factors influence food preferences in Samoa. These factors are of significance for public health since policy designed to address non-communicable diseases needs to consider linkages among economic modernization, food preferences, potential health impacts and affordability of food choices (Evans et al. 2003).

\section{Materials and Methods}

A total of 51 interviews were conducted with Samoans of different age groups in the rural village of Saipipi, Savai' i (population of approx. 700) and in Apia, Upolu (population of approx. 60,000), the capital and most urbanized city in Samoa. All interviews were conducted in English or Samoan based on the participant's preference with an interviewer, a recorder, and one of several local translators present. At the beginning of the interview the purpose of the research was outlined and the interview was initiated only after consent was obtained from the respondent. In the first part of the interview standard baseline demographic data was collected, including the participant's name, age, gender, hometown, education, occupation and religion. The subjects were then presented with a set of cards with the English and Samoan names of the ten most common starchy staple foods: banana, bread, breadfruit, elephant ear, noodles, potato, rice, tapioca, taro and yam. The respondent was then asked to rank the cards according to their personal preference. After ranking, the participants were asked to explain their reasoning behind their favorite and least favorite choices. The cards were then reassembled randomly and interviewees were asked to group the cards in any manner that seemed sensible to them and were asked to explain what criteria was used in their categorization process. The respondents were then asked to name which they perceived as the most and least healthy options. When 'noodles' was selected as the least healthy food item, the respondents were asked to name the second least healthy option as well. This was done after the first few participants gave unexpected answers regarding the health consequences of eating noodles. This exercise was followed up by asking the subjects why they thought the selected items were the most/least healthy. Finally, all interviewees who were older than 30 years were asked what food items they predominately ate when they were children; interviewees who were younger than 30 were asked what they thought their parents had eaten when they were their age. The average age of the interviewees was 23.3 years, the youngest interviewee was 7 years old 


\section{Jones et al. - Staple food choices in Samoa: Do changing dietary trends reflect local food preferences?}

and the oldest was 78 years of age; $49 \%$ were female and $51 \%$ were male. Thirty seven percent of interviewees pursued employment outside their home.

Statistical analyses of food preferences were conducted using JMP ${ }^{\circledR}$ 8.0.1 (SAS Institute, NC, USA). An analysis of variance was conducted within each group (age group, sex) comparing the ranking of food items to determine if there were statistically significant differences in the food item preference and among the ranking of individual food items between males/females and adults/children to determine if the food items were differentially preferred between groups. In cases where the model was significant, a means separation was conducted to determine the specific differences. An analysis of variance was also used to determine if there were any significant interactions between age and the preference for each food item; a correlation analysis was conducted where applicable.

\section{Results}

The average rank for each of the various starchy food items selected by the sample population is presented in Table 1. There was no significant difference in the average rank for any food items between children ( $<18$ years old) and adults ( $>=18$ years old). However, there was a significant positive correlation between age and preference for breadfruit $(p=0.0166, R=0.3408)$ and a significant negative correlation between age and preference for tapioca $(p=0.0356, R=0.3041)$. The ranking of food items between males and females was statistically similar with the exception that men ranked taro and elephant ear significantly more preferable than women did.
A modest majority (31/52) of participants reported that they thought taro was the healthiest of the food items. The frequencies of various responses to this question are displayed in Table 2. When asked which of the food items was the least healthy, noodles was the most common response. Table 3 shows the frequency of responses to this question. When asked why they preferred the item that they selected as their favorite and disliked the item they selected as their least favorite, interviewees had a variety of responses. The three most common reasons for liking the selected foods were that they provide a lot of energy for a long time, they taste good, or that they are traditional Samoan food. The three most common reasons for disliking the selected foods were that they did not provide enough energy, they caused the throat to itch, or that they do not taste good. When asked why they selected the specific foods as the most and least healthy, a similar diversity in responses was observed. The three most common explanations given by respondents for why they believe a food is healthy were that they provide a lot of energy and make you strong, they are not overly starchy, or that their elders have told them that these are healthy foods. The three most common reasons for selecting the least healthy item were that they make you 'sick', that they do not 'fill one up' or that they are 'foreign.' When asked to group the food items they thought best fit together, three general methods were most commonly employed; Samoan vs. imported foods, nutritional qualities, or a grouping based on personal preference. When asked what the older respondents (those 30 years and over), or the respondents' parents ate as children (those under 30 years), the most common responses were the crops traditionally cultivated in Samoa. A detailed breakdown of the response to these questions is depicted in Table 4.

Table 1. Average preference ranking of selected starchy foods by the Samoan sample population ( $n=51)$. Foods were ranked in order from most to least favorite, lower values represent more preferable food items. Means within a group followed by same letter (a-e) are not significantly different at $p=0.05$. Standard Error (SE) is the standard deviation of the sample distribution.

\begin{tabular}{|c|c|c|c|c|c|c|c|c|c|c|c|}
\hline & \multicolumn{3}{|c|}{ Total Population } & \multicolumn{2}{|l|}{ Males } & \multicolumn{2}{|c|}{ Females } & \multicolumn{2}{|c|}{ Children $(<18)$} & \multicolumn{2}{|c|}{ Adults (>=18) } \\
\hline & Food Item & $\begin{array}{l}\text { Avg } \\
\text { Rank }\end{array}$ & SE & $\begin{array}{l}\text { Avg } \\
\text { Rank }\end{array}$ & SE & $\begin{array}{l}\text { Avg } \\
\text { Rank }\end{array}$ & SE & $\begin{array}{l}\text { Avg } \\
\text { Rank }\end{array}$ & SE & $\begin{array}{l}\text { Avg } \\
\text { Rank }\end{array}$ & SE \\
\hline \multirow[t]{8}{*}{ Favorite } & Taro & $2.7 a$ & 0.29 & $1.8 \mathrm{a}$ & 0.23 & $3.7 \mathrm{ab}$ & 0.51 & $3.2 a$ & 0.47 & $2.2 a$ & 0.36 \\
\hline & Yam & $2.8 a b$ & 0.27 & $2.8 a$ & 0.37 & $2.9 a$ & 0.40 & $2.8 a$ & 0.41 & $2.8 a b$ & 0.35 \\
\hline & Banana & $3.7 \mathrm{~b}$ & 0.31 & $4.1 \mathrm{~b}$ & 0.39 & $3.4 a$ & 0.47 & $3.8 a b$ & 0.48 & $3.7 b$ & 0.40 \\
\hline & Rice & $5.4 \mathrm{c}$ & 0.41 & $5.8 \mathrm{c}$ & 0.61 & $4.9 \mathrm{bc}$ & 0.53 & $5.2 \mathrm{bc}$ & 0.54 & $5.5 \mathrm{c}$ & 0.54 \\
\hline & Breadfruit & $5.7 \mathrm{c}$ & 0.32 & $5.4 \mathrm{c}$ & 0.45 & $6.0 \mathrm{~cd}$ & 0.45 & $6.3 \mathrm{cde}$ & 0.43 & $5.2 \mathrm{c}$ & 0.61 \\
\hline & Potato & $5.8 \mathrm{c}$ & 0.39 & $5.5 \mathrm{c}$ & 0.53 & $6.0 \mathrm{~cd}$ & 0.58 & $5.5 \mathrm{~cd}$ & 0.57 & $6.0 \mathrm{~cd}$ & 0.54 \\
\hline & Elephant ear & $6.2 \mathrm{~cd}$ & 0.43 & $4.9 \mathrm{bc}$ & 0.55 & $7.7 \mathrm{e}$ & 0.52 & $6.8 \mathrm{de}$ & 0.62 & $5.6 \mathrm{~cd}$ & 0.45 \\
\hline & Tapioca & 7.1de & 0.37 & $7.3 d$ & 0.50 & 7.0de & 0.56 & $6.5 \mathrm{cde}$ & 0.49 & $7.7 \mathrm{e}$ & 0.60 \\
\hline \multirow{2}{*}{$\begin{array}{r}\text { Least } \\
\text { Favorite }\end{array}$} & Bread & $7.2 \mathrm{de}$ & 0.27 & $7.4 d$ & 0.35 & 6.9de & 0.42 & $7.3 e$ & 0.36 & $7.1 \mathrm{de}$ & 0.58 \\
\hline & Noodles & $7.5 \mathrm{e}$ & 0.43 & $8.2 d$ & 0.51 & $6.7 \mathrm{de}$ & 0.69 & $7.5 \mathrm{e}$ & 0.63 & $7.5 \mathrm{e}$ & 0.40 \\
\hline $\mathrm{n}=$ & & \multicolumn{2}{|c|}{51} & \multicolumn{2}{|c|}{26} & \multicolumn{2}{|c|}{25} & \multicolumn{2}{|c|}{24} & \multicolumn{2}{|c|}{27} \\
\hline
\end{tabular}


Table 2. Frequency that food items were selected as the healthiest of the available items by the Samoan sample population $(n=51)$. Number of selections may not add to $n$ as some participants did not select any items, while others selected more than one.

\begin{tabular}{|l|c|c|c|c|c|}
\hline \multirow{2}{*}{ Food Item } & \multicolumn{5}{|c|}{ Times Selected } \\
\cline { 2 - 6 } & Total Population & Males & Females & Children (<18) & Adults (>=18) \\
\hline Taro & 31 & 19 & 12 & 10 & 21 \\
\hline Yam & 13 & 7 & 6 & 5 & 8 \\
\hline Banana & 11 & 3 & 8 & 3 & 8 \\
\hline Rice & 5 & 0 & 1 & 5 & 1 \\
\hline Breadfruit & 3 & 0 & 3 & 2 & 3 \\
\hline Potato & 2 & 0 & 0 & 0 & 1 \\
\hline Elephant ear & 1 & 2 & 1 & 0 & 2 \\
\hline Tapioca & 1 & 0 & 0 & 1 & 1 \\
\hline Bread & 1 & 1 & 0 & 0 & 0 \\
\hline Noodles & 0 & 0 & 25 & 24 & 27 \\
\hline
\end{tabular}

Table 3. Frequency that food items were selected as the least healthy of the available items by the Samoan sample population $(n=51)$. Number of selections may not add to $n$ as some participants did not select any items while others selected more than one.

\begin{tabular}{|c|c|c|c|c|c|}
\hline \multirow[t]{2}{*}{ Food Item } & \multicolumn{5}{|c|}{ Times Selected } \\
\hline & Total Population & Males & Females & Children (<18) & Adults (>=18) \\
\hline Breadfruit & 0 & 0 & 0 & 0 & 0 \\
\hline Banana & 1 & 0 & 1 & 0 & 1 \\
\hline Taro & 2 & 1 & 1 & 0 & 2 \\
\hline Potato & 2 & 1 & 1 & 1 & 1 \\
\hline Elephant ear & 2 & 0 & 2 & 1 & 1 \\
\hline Yam & 3 & 0 & 3 & 1 & 2 \\
\hline Tapioca & 5 & 3 & 2 & 1 & 4 \\
\hline Rice & 11 & 6 & 5 & 4 & 7 \\
\hline Bread & 21 & 12 & 9 & 10 & 11 \\
\hline Noodles & 33 & 19 & 14 & 18 & 15 \\
\hline $\mathrm{n}=$ & 51 & 26 & 25 & 24 & 27 \\
\hline
\end{tabular}

Table 4. Frequency of different types of responses to the interview questions received from Samoan sample population $(\mathrm{n}=51)$.

\begin{tabular}{|l|l|c|}
\hline Question & Responses & $\begin{array}{c}\text { Response } \\
\text { frequency }\end{array}$ \\
\hline \multirow{3}{*}{$\begin{array}{l}\text { Why did you select this as } \\
\text { your favorite food? }\end{array}$} & It is nutritious/sustaining. & $42 \%$ \\
\cline { 2 - 3 } & They like the flavor/texture. & $26 \%$ \\
\cline { 2 - 3 } & It is a Samoan food. & $16 \%$ \\
\cline { 2 - 3 } & They just like it. & $5 \%$ \\
\cline { 2 - 3 } & It is a light food. & $4 \%$ \\
\cline { 2 - 3 } & It is rare or not eaten often. & $3 \%$ \\
\cline { 2 - 3 } & It's versatility. & $3 \%$ \\
\hline
\end{tabular}


Jones et al. - Staple food choices in Samoa: Do changing dietary trends reflect local food preferences?

\begin{tabular}{|c|c|c|}
\hline Question & Responses & $\begin{array}{l}\text { Response } \\
\text { frequency }\end{array}$ \\
\hline \multirow{6}{*}{$\begin{array}{l}\text { Why did you select this as } \\
\text { your least favorite food? }\end{array}$} & It is not healthy/doesn't provide sustenance. & $52 \%$ \\
\hline & It makes their throat itchy. & $18 \%$ \\
\hline & They don't like the flavor/texture. & $14 \%$ \\
\hline & It is foreign. & $12 \%$ \\
\hline & It is a "heavy" food. & $2 \%$ \\
\hline & It is expensive. & $2 \%$ \\
\hline \multirow{6}{*}{$\begin{array}{l}\text { What about the item you selected } \\
\text { as the healthiest makes it healthy? }\end{array}$} & It gives strength. & $62 \%$ \\
\hline & It is not too starchy. & $10 \%$ \\
\hline & The elders say it is healthy. & $8 \%$ \\
\hline & It can be eaten alone ("complete" food). & $4 \%$ \\
\hline & It is used as a vegetable. & $4 \%$ \\
\hline & Other. & $12 \%$ \\
\hline \multirow{8}{*}{$\begin{array}{l}\text { What about the item you selected as } \\
\text { the least healthy makes it unhealthy? }\end{array}$} & It makes you sick. & $29 \%$ \\
\hline & It does not fill you up. & $29 \%$ \\
\hline & It is foreign/imported. & $9 \%$ \\
\hline & It is processed. & $7 \%$ \\
\hline & It is too salty. & $6 \%$ \\
\hline & It is too starchy. & $5 \%$ \\
\hline & It makes you itchy. & $4 \%$ \\
\hline & Other. & $11 \%$ \\
\hline \multirow{3}{*}{$\begin{array}{l}\text { What criteria did you use to sort } \\
\text { the food items into groups? }\end{array}$} & Samoan vs. imported foods. & $55 \%$ \\
\hline & Based on nutritional qualities. & $31 \%$ \\
\hline & Based on personal preference. & $14 \%$ \\
\hline \multirow{10}{*}{$\begin{array}{l}\text { Of these foods, what did you (or } \\
\text { your parents if under } 30 \text { years old) } \\
\text { eat when you/they were children? }\end{array}$} & Taro & $88 \%$ \\
\hline & Banana & $67 \%$ \\
\hline & Breadfruit & $64 \%$ \\
\hline & Elephant ear & $64 \%$ \\
\hline & Yam & $64 \%$ \\
\hline & Tapioca & $28 \%$ \\
\hline & Rice & $16 \%$ \\
\hline & Bread & $4 \%$ \\
\hline & Noodles & $4 \%$ \\
\hline & Potatoes & $4 \%$ \\
\hline
\end{tabular}

\section{Discussion}

These data greatly enhance our understanding of food preferences among Samoans. The interview results also provide insight into how the Samoan population perceives, understands, and categorizes diverse food items and what criteria they use to form their opinions. Based on the average rank assigned to each of the ten foods, the items can be placed into three general groups. The first group includes taro, yam, and bananas and represents the items that were consistently ranked as favor- ites. The second group includes rice, breadfruit, potato and elephant ear; these foods were generally ranked in the middle. The final group, ranked as the least favorite, included tapioca, bread and noodles. The most common reason given for what they liked about their favorite of the selected food items was that they provide a longer lasting source of 'energy' or 'strength', an important attribute for the physically demanding lifestyle typical of most Samoans. This response was especially common among the participants that selected yam and taro as their favorite, while banana was often selected based on flavour. 
Likewise, one of the primary reasons given for disliking a particular food item was that it did not provide a long lasting source of 'energy' or 'strength'. This observation can be verified by comparing the glycemic indices (GI), a measure of the effect of carbohydrate-containing foods on blood glucose levels over time (Roberts 2000), of the selected crops. Although results are often variable and long term studies are lacking, consumption of high GI carbohydrates appears to increase hunger and promote overeating (Roberts 2000). The GI of taro, yam, green banana, white rice, breadfruit, potato, white bread and cassava have been reported as 47.7, 51.0, 65, 83.2, 60, 66.4, 87.9 and 94 respectively (Ramdath et al. 2004, Yang et al. 2006). Interestingly, there is a significant correlation between the $\mathrm{Gl}$ of the food items and the average rank they received (Figure $1 ; p=0.006, R=0.86$ ), supporting the Samoan perception regarding the amount of 'energy' or 'strength' these foods provide.

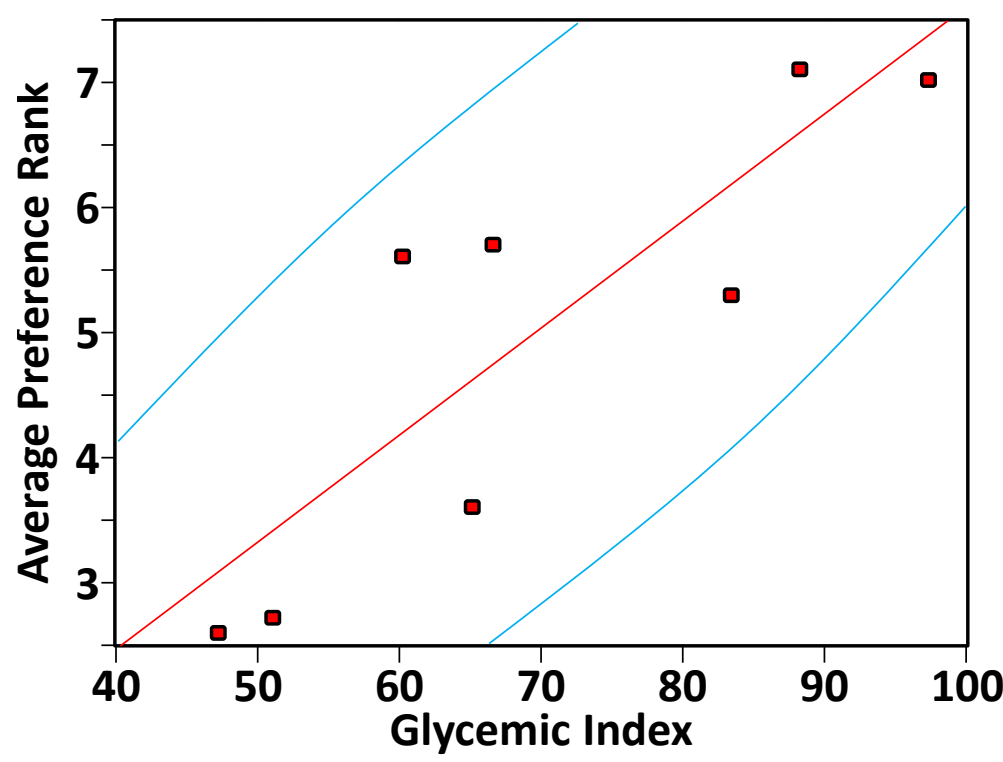

Figure 1. Correlation between glycemic index and preference ranking (lower numbers represent more preferable) of selected staple foods in Samoa (taro, yam, green banana, white rice, breadfruit, potato, white bread and cassava). P-value $=0.0062, R=0.86$. Glycemic index values are based on data from Ramdath et al. 2004 and Yang et al. 2006.

The original hypothesis that the younger generation would rank recently introduced foods (rice, bread, and noodles) as more preferable than would the older generation received no significant support. Despite the lack of discrete differences in the ranks given by children and adults, there was a positive correlation between age and preference for breadfruit and a negative correlation between age and preference for tapioca. There was no clear reasoning apparent for the trend observed with breadfruit, but the dislike for tapioca appears to be related to the perception of it as a famine food which is only eaten in times of food scarcity. Tapioca, which is made from extracting starch from cassava, was typically not regarded as a staple food by many of the participants.

The difference between the food preferences of males and females was more pronounced than differences between age groups. The significant differences were that males ranked taro and elephant ear higher than women did. The reason for the differential preference of taro was not explicitly clear from this study; however, men typically do more extensive physical work on the plantation and these food items were frequently reported to provide more energy for a longer period of time than many of the others. Women disliked elephant ear because they claimed it caused their throats to itch. This phenomenon was widely acknowledged by the Samoan participants and appears to be due to the presence of calcium oxalate crystals commonly found in this plant family (Sunell \& Healy 1979). During the interviews it was explained to us that because the crystals are primarily found in the outer tissue of the corm, they can cause significant irritation if the elephant ear is not prepared properly. Based on the difference between males and females it is possible that women are more sensitive to this effect than men. Another difference was that the men were more consistent with their choices, reflected by the lower standard error of the mean ranks and the wider spread of the means shown in Table 1. Some other trends observed were that women ranked bananas, rice, and noodles as more preferable than men, however, these differences were not statistically significant. These trends may be verified or disproven in the future in a larger sample population.

The Samoan perception of which staple foods are healthy was most often related to the food's ability to provide energy and long-term satisfaction. As mentioned above, their perception of these attributes agrees well with the documented glycemic indexes of these foods. More generally, the order of foods listed from healthiest to the least healthy mirrored the ranking from their favorite to their least favorite. The one major exception to this ranking was with rice, which was moderately liked even though about $21 \%$ of all participants selected it as the least healthy item. As with food preference, children and adults generally agreed on healthy foods, though there were several differences between males and females. Most notably, females ranked breadfruit and banana as healthy food items more often than males, while males more consistently selected taro. It is also interesting to note that the general consensus was that the imported foodstuffs, with the exception of potato, were considered 


\section{Jones et al. - Staple food choices in Samoa: Do changing dietary trends reflect local food preferences?}

the least healthy options. Potatoes were perceived by some participants not as a starch but as a vegetable and were therefore considered to be a healthier choice.

The exercise which asked the participants to group the food items was included in order to determine how Samoans view and classify diverse starchy foods. The majority of the participants, both young and old, grouped the items based on their source, with considerations such as whether the foods were Samoan vs. imported or cultivated vs. purchased. The other two sorting methods used by participants were based on nutritional qualities or individual preference. When asked to select the items that they ate as children, or what they thought their parents ate as children, they generally selected the traditional Samoan staples. This indicates that Samoans, young and old, are acutely aware of where their food comes from and that the foreign foods have been only recently introduced.

Overall, the results of this study indicate that Samoans prefer the staple crops traditionally grown in Samoa to the more recently imported foods. This preference is the result of many factors; however, it seems that their perception of the nutritional quality of the various crops is a significant one. This raises the obvious question: if Samoans prefer their traditional staple crops, why has the importation and consumption of rice and wheat grown in recent years? A similar trend observed in Tonga has been attributed to the lower cost and the higher availability of imported foods (Evans et al. 2001). Evans et al. found that although Tongans were health conscious, they purchased cheap imported foods despite the health implications of consuming them because it made economic sense. The reasons for doing this in Samoa appear to be similar to those discovered in Tonga. Even though Samoans understand the health consequences of their food choices and have a desire to eat well, the imported cereal-based products provide more calories at a lower cost than most of the locally produced traditional crops (Table 5). For ex-

Table 5. Average 2009 local price (tala/kg), energy content $(\mathrm{kcal} / \mathrm{kg})$, and amount of energy provided per tala (kcal/tala) of 8 starchy staple foods commonly found in Samoa. Data compiled from Dignan et al. 2004 and Reupena 2009.

\begin{tabular}{|l|c|c|c|}
\hline Food Item & $\begin{array}{c}\text { Average retail } \\
\text { price (tala/kg) }\end{array}$ & $\begin{array}{c}\text { Energy } \\
\text { (kcal/kg) }\end{array}$ & kcal/tala \\
\hline Rice & 3.19 & 3700 & 1160 \\
\hline Banana & 1.474 & 1240 & 841 \\
\hline Flour (wheat) & 4.444 & 3490 & 758 \\
\hline Breadfruit & 1.408 & 1070 & 760 \\
\hline Yam & 3.058 & 1960 & 641 \\
\hline Potatoes & 2.904 & 1080 & 372 \\
\hline Taro & 3.102 & 970 & 313 \\
\hline Elephant ear & 3.476 & 1020 & 293 \\
\hline
\end{tabular}

ample, rice and wheat both provide more calories per tala (Samoan currency) than taro or yam. In addition to the lower cost per calorie of imported cereals, they may also be more convenient, often requiring less work to prepare than many of the traditional food items. Some participants alluded to this factor during the interviews.

As a greater proportion of Samoans move to urban centers and the economy becomes more cash-based, the tendency to eat less expensive, more convenient food is likely to increase. This shift is likely to be accompanied by a further increase in diet-related health conditions such as obesity and diabetes. It is evident from the current study that Samoans are health conscious about their eating habits. Future public health policies in Samoa need to focus on increasing production or reducing the cost of local staple food items to capitalize on these preferences and increase their consumption. Efforts should be made to develop products containing traditional staple foods that require less preparation to be more compatible with the urban lifestyle. It would also be advantageous to develop policies that encourage the importation of whole wheat and brown rice products over the currently available refined cereal products.

\section{Acknowledgments}

We would like to express our deepest gratitude to the Matai and their families in Saipipi and Apia for their generous hospitality and participation in the study. Special thanks also go out to Ms. Asu Tuamalo and Ms. Arleen Sefo for providing translations during the interview process.

\section{Literature Cited}

Collins, V.R. , G.K. Dowse, P.M. Toelupe, T.T. Imo, F.L. Aloaina, R.A. Spark \& P.Z. Zimmet. 1994. Increasing prevalence of NIDDM in the Pacific Island population of Western Samoa over a 13-year period. Diabetes Care 17(4):288-296.

Coyne, T. 2000. Lifestyle Diseases in Pacific Communities. Secretariat of the Pacific Community, Noumea, New Caladonia.

Dignan, C., B. Burlingame, S. Kumar \& W. Aalbersberg. 2004. The Pacific Islands Food Composition Tables. Second Edition. Food and Agriculture Organization of the United Nations, Rome, Italy.

Evans, J., R.C. Sinclair, C. Fusimalohi, V. Laiva`a \& M. Freeman. 2003. Consumption of traditional versus imported foods in Tonga: Implications for programs designed to reduce diet-related non-communicable diseases in developing countries. Ecology of Food and Nutrition 42:153176. 
Hodge, A.M., G.K. Dowse, P. Toelupe, V.R. Collins, T. Imo \& P.Z. Zimmet. 1994. Dramatic increase in the prevalence of obesity in Western Samoa over the 13 year period 1978-1991. International Journal of Obesity 18(6):419428.

Holmes, L.D. 1958. Ta'u: Stability and change in a Samoan village. The Polynesian Society Incorporated, Wellington, New Zealand.

Galanis, D.J., S.T. McGarve, C. Quested, B. Sio \& S. Afele-Fa`amuli. 1999. Dietary intake among modernizing Samoans: implications for risk of cardiovascular disease. Journal of the American Dietetic Association 99:184-190.

Galanis, D.J., J. Sobal, S.T. McGarvey, D.L. Pelletier \& L. Bausserman. 1995. Ten-year changes in the obesity, abdominal adiposity, and serum lipoprotein cholesterol measures of western Samoan men. Journal of Clinical Epidemiology 48(12):1485-1493.

Quested, C., O. Liu \& J. Lamb. 1992. Western Samoa: Country paper (English). International Conference on Nutrition. Government of Western Samoa, Apia, Samoa. Accession No: 343107 Fiche No: 343107, 56

Ramdath, D.D., R.L.C. Isaacs, S. Teelucksingh \& T.M.S. Wolever. 2004 Glycaemic index of selected staples com- monly eaten in the Caribbean and the effects of boiling v. crushing. British Journal of Nutrition 91:971-977.

Reupena, M.S. 2009. Consumer Price Index - October 2009. Samoa Bureau of Statistics, Apia, Samoa.

Roberts, S.B. 2000. High-glycemic Index Foods, Hunger, and Obesity: Is There a Connection? Nutrition Reviews 58(6):163-169.

Sunell, L.A. \& P.L. Healy. 1979. Distribution of calcium oxalate crystal idioblasts in corms of taro (Colocasia esculenta). American Journal of Botany 66(9):1029-1032.

Watters, R.F. 1958. Cultivation in Old Samoa. Economic Geography 34(4):338-351.

Whistler, W.A. 2000. Plants in Samoan Culture, the Ethnobotany of Samoa. Isle Botanica, Honolulu, Hawai'i.

WHO. 1990. Diet, Nutrition, and the Prevention of Chronic Diseases: Report of a WHO Study Group. World Health Origination, Technical Report Series No. 797, Geneva, Switzerland.

Yang, Y., H. Wang, H. Cui, Y. Wang, L. Yu, S. Xiang \& S. Zhou. 2006 Glycemic index of cereals and tubers produced in China. World Journal of Gastroenterology 12(21):3430-3433. 